\title{
The antitumor activities of curcumin and of its isoxazole analogue are not affected by multiple gene expression changes in an MDR model of the MCF-7 breast cancer cell line: Analysis of the possible molecular basis
}

\author{
PAOLA POMA ${ }^{1}$, MONICA NOTARBARTOLO ${ }^{1}$, MANUELA LABBOZZETTA ${ }^{1}$, \\ ANNAMARIA MAURICI ${ }^{1}$, VALERIA CARINA $^{1}$, ALESSANDRA ALAIMO $^{1}$, \\ MICHELE RIZZI $^{2}$, DANIELE SIMONI ${ }^{2}$ and NATALE D'ALESSANDRO ${ }^{1}$ \\ ${ }^{1}$ Department of Pharmacological Sciences, University of Palermo, Via del Vespro 129, 90127 Palermo; \\ ${ }^{2}$ Department of Pharmaceutical Sciences, University of Ferrara, Via Fossato di Mortara 17/19, 44100 Ferrara, Italy
}

Received March 23, 2007; Accepted April 26, 2007

\begin{abstract}
We examined the effects of curcumin and of its isoxazole analogue MR 39 in the MCF-7 breast cancer cell line and in its multidrug-resistant (MDR) variant MCF-7R. In comparison with MCF-7, MCF-7R lacks estrogen receptor $\alpha$ $(\mathrm{ER} \alpha)$ and overexpressess $\mathrm{P}$-glycoprotein (P-gp), different IAPs (inhibitory of apoptosis proteins) and COX-2. Through analyses of the effects on cell proliferation, cycling and death, we have observed that the antitumor activity of curcumin and of the more potent (approximately two-fold) MR 39 is at least equal in the MDR cell line compared to the parental MCF-7. Similar results were observed also in an MDR variant of HL-60 leukemia. RT-PCR evaluations performed in MCF-7 and MCF-7R showed that curcumin or MR 39 produced early modifications in the amounts of relevant gene transcripts, which, however, were mostly diverse (i.e. represented by decreases in IAPs and COX-2 in MCF-7R versus reductions in $\mathrm{Bcl}-2$ and $\mathrm{Bcl}-\mathrm{X}_{\mathrm{L}}$ as well as increases in the $\mathrm{Bcl}-\mathrm{X}_{\mathrm{S}} / \mathrm{Bcl}-\mathrm{X}_{\mathrm{L}}$ ratio in MCF-7) in the two cell lines. These results could not be explained by an involvement of NF- $\mathrm{KB}$ (p65 subunit) or STAT3, since the low nuclear levels of these transcription factors present in MCF-7 were only slightly, though significantly, elevated in MCF-7R; moreover, curcumin or MR 39 caused minor changes in NF- $\mathrm{kB}$ or STAT3 activation. Overall, these data underline that curcumin or MR 39 antitumor activities are not hampered by P-gp expression or lack of $\mathrm{ER} \alpha$ in breast cancer cells. Remarkably, the agents appeared to modify their molecular effects according to the diverse gene
\end{abstract}

Correspondence to: Professor Natale D'Alessandro, Department of Pharmacological Sciences, University of Palermo, Via del Vespro 129, 90127 Palermo, Italy

E-mail: dalessan@unipa.it

Key words: curcumin, isoxazole derivative, multidrug resistance, P-glycoprotein, estrogen receptor, inhibitory of apoptosis proteins expression patterns existing in the MDR and in the parental MCF-7. Clearly, the structure and properties of curcumin can form the basis for the development of antitumor compounds that are more effective against both chemosensitive and MDR cells.

\section{Introduction}

Drug resistance, either innate or acquired and especially in its multiple form (multidrug resistance, MDR), remains a major and difficult problem to resolve in the therapy of many cancer types. This process has previously been interpreted on the basis of the ability of tumor cells to extrude or inactivate the cytotoxic agents or to modify their targets of action: much attention has been drawn to the overexpression of multidrug efflux transporters such as P-glycoprotein (P-gp), Multidrug Resistance Related Proteins (MRPs), Breast Cancer Resistance Protein (BCRP) and others. Nevertheless, today it is recognized that clinical MDR is often a multifactorial and heterogeneous process and that many other different molecular alterations involved in the malignant transformation and progression may be responsible for tumor drug resistance as well (1). For example, induction of tumor cell killing is fundamental for the efficacy of anticancer drugs and a critical mechanism of cellular protection from their attacks is represented by the loss of pro-apoptotic factors (e.g., functional p53 or Bax) or the overexpression of anti-apoptotic factors, such as Bcl-2, $\mathrm{Bcl}-\mathrm{X}_{\mathrm{L}}$ or IAPs (inhibitory of apoptosis proteins) $(1,2)$. IAPs, which in humans include c-IAP-1, c-IAP-2, XIAP, NAIP, survivin and livin- $\alpha$, as well as other anti-apoptotic mechanisms, possess the ability of interfering with the terminal cell death effector caspases. Similarly to Bcl-2 or Bcl- $\mathrm{X}_{\mathrm{L}}$, they can block the execution of cell death triggered by many nonrelated stimuli $(3,4)$. It is also recognized that survivin not only inhibits apoptosis but also, as a component of the chromosomal passenger complex, favours cancer cell proliferative activity (5).

The multiplicity of the drug resistance determinants poses the question of the optimal strategies to face them; reasonably, 
<smiles>COc1cc(/C=C/C(=O)CC(=O)/C=C/c2ccc(O)c(OC)c2)ccc1O</smiles>

CURCUMIN<smiles>COc1cc(/C=C/c2cc(/C=C/c3ccc(O)c(OC)c3)on2)ccc1O</smiles>

MR 39

Figure 1. Chemical structures of curcumin and of its isoxazole analogue MR 39.

multi-targeted agents might be less likely to encounter problems of drug resistance than single-targeted agents. In this respect, there is increasing evidence that the dietary polyphenols are endowed with a remarkable number of different antitumor mechanisms, yet accompanied by a limited toxicity for normal cells. Among these agents, curcumin (diferuloylmethane), extracted from Curcuma longa L. and present in curry spice, has a long history of use in Indian medicine for anti-inflammatory and other therapeutic purposes; it has exhibited definite tumor suppressive and preventive activities in many in vitro and in vivo models (reviewed in ref. 6). Here, we have tried to corroborate the possible evidence that this compound, owing to its pleiotropic properties, may be favored in evading tumor drug resistance. We have examined the effects of curcumin and of its novel, more potent, isoxazole analogue (hereafter named MR 39, Fig. 1) in the MCF-7 breast cancer cell line and in its MCF-7R variant endowed with different mechanisms [lack of estrogen receptor (ER) $\alpha$ and overexpression of P-gp and different IAPs] of drug resistance.

\section{Materials and methods}

Agents. Curcumin was purchased from Sigma-Aldrich Srl, Milan, Italy. The isoxazole derivative of curcumin, MR 39, was synthesized and provided by Professor Daniele Simoni, Dipartimento di Scienze Farmaceutiche, Università di Ferrara.

Cell lines and culture conditions. The human breast cancer cell line MCF-7 was obtained from Doctor Giuseppe Carruba, M. Ascoli Cancer Hospital Center, Palermo, Italy. The MDR cell line MCF-7R was established treating the wild-type cells with gradually increasing concentrations of doxorubicin. The $\mathrm{IC}_{50}$ value of doxorubicin in MCF-7R is $17.1 \mu \mathrm{M}$ as determined by cell vitality tests, which is approximately 92 times higher than the original $\mathrm{IC}_{50}$. In contrast to MCF-7, MCF-7R lacks $\mathrm{ER} \alpha$ expression, is estrogen-insensitive and overexpresses P-gp, as determined in our laboratory by analyses of mRNA and protein expression and by cell vitality tests examining the response of the cells to diethylstilbestrol and tamoxifen. The cells were cultured in Roswell Park Memorial Institute (RPMI)1640 (HyClone Europe Ltd, Cramlington, UK) supplemented with $10 \%$ heat-inactivated fetal calf serum, $2 \mathrm{mM} \mathrm{L-glutamine,}$
$1 \mathrm{mM}$ sodium pyruvate, 100 units $/ \mathrm{ml}$ penicillin and $100 \mu \mathrm{g} / \mathrm{ml}$ streptomycin (all reagents were from HyClone Europe) in a humidified atmosphere of $5 \% \mathrm{CO}_{2}$ at $37^{\circ} \mathrm{C}$.

Cytotoxicity assays. The cells were seeded at $1 \times 10^{4} /$ well onto 96-well plates and then incubated overnight. At time 0 , the medium was replaced with fresh complete medium and curcumin or MR 39 was added in various concentrations. After $72 \mathrm{~h}, 15 \mu \mathrm{l}$ of a commercial solution (obtained from Promega Corporation, Madison, WI, USA) containing 3(4,5-dimethylthiazol-2-yl)-5-(3-carboxymethoxyphenyl)-2(4-sulphophenyl)-2H-tetrazolium (MTS) and phenazine ethosulfate were added. The plates were incubated for $2 \mathrm{~h}$ in a humidified atmosphere of $5 \% \mathrm{CO}_{2}$ at $37^{\circ} \mathrm{C}$. The bioreduction of the MTS dye was assessed by measuring the absorbance of each well at $490 \mathrm{~nm}$. Cytotoxicity was expressed as a percentage of the absorbance measured in the control cells.

Cell proliferation assays. The ability of the agents to inhibit DNA synthesis was determined by estimating the amount of bromodeoxyuridine (BrdU) incorporation into DNA by a colorimetric immunoassay (Roche Diagnostics GmbH, Mannheim, Germany). Briefly, cells were cultured in 96-well plates $\left(2.5 \times 10^{3}\right)$ in the presence of the agents for $24 \mathrm{~h}$. BrdU (10- $\mu \mathrm{M}$ final concentration) was added, and the cells were re-incubated for an additional $24 \mathrm{~h}$. The cells were fixed and incubated with anti-BrdU-POD (100 $\mu \mathrm{l}$ per well) for $2 \mathrm{~h}$ at room temperature. The color, directly correlating to the amount of BrdU incorporated into DNA, was developed by the addition of tetramethylbenzidine substrate and measured at $490 \mathrm{~nm}$. The results were expressed as percent inhibition of BrdU incorporation over the control.

Evaluation of cell cycle and cell death by flow cytometry. Cells were washed twice with ice-cold PBS and then resuspended at $1 \times 10^{6} / \mathrm{ml}$ in a hypotonic fluorochrome solution containing propidium iodide $50 \mu \mathrm{g} / \mathrm{ml}$ in $0.1 \%$ sodium citrate plus $0.03 \%$ (v/v) Nonidet P-40. After $1 \mathrm{~h}$ of incubation in this solution the samples were filtered through nylon cloth, $40-\mu \mathrm{m}$ mesh, and their fluorescence was analyzed as single-parameter frequency histograms using a FACSort instrument (Becton Dickinson, Montain View, CA, USA). The data were analyzed with CellQuest ${ }^{\mathrm{TM}}$ and ModFit ${ }^{\mathrm{TM}}$ softwares (Becton Dickinson). Cell death was determined by evaluating the percentage of events accumulated in the $\mathrm{preG}_{0}-\mathrm{G}_{1}$ position. To assess the phosphatidylserine on the cell surface, the cells were resuspended at $1 \times 10^{6} / \mathrm{ml}$ in binding buffer $(10 \mathrm{mM}$ HEPES/NaOH, $\mathrm{pH} 7.4,140 \mu \mathrm{M} \mathrm{NaCl}$ and $2.5 \mathrm{mM} \mathrm{CaCl}_{2}$ ), incubated with FITC-conjugated annexin V (Pharmingen, San Diego, CA) and then analyzed by flow cytometry.

Evaluation of gene expression by RT-PCR. Total RNA was isolated from $1 \times 10^{6}$ cells using Trizol reagent (Invitrogen, Carlsbad, CA, USA). RT-PCR was then performed using the one-step protocol of the Ready-to-go RT-PCR beads kit (Amersham, Little Chalfont, UK). Quantification and equalization of the amount of cDNA was achieved using primers to amplify $B$-actin as an internal control. The conditions and sequences of primers used to obtain the different RT-PCR products have been previously described (7). All PCR products 


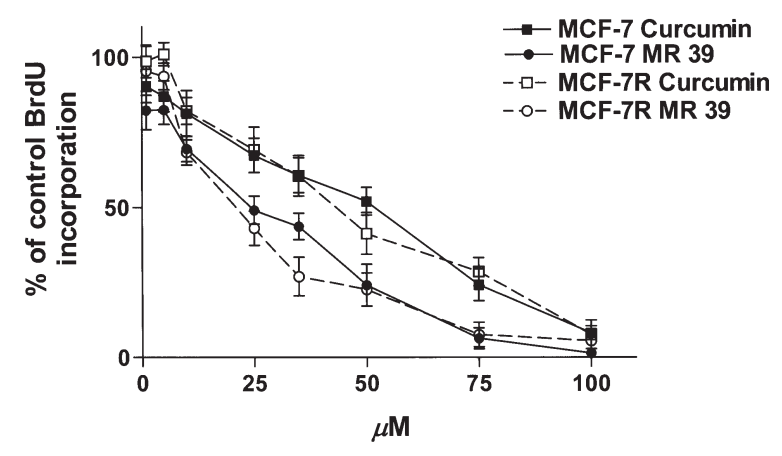

Figure 2. Cell proliferation inhibitory effects of the agents on MCF-7 and MCF-7R. After $48 \mathrm{~h}$ of exposure to curcumin or MR 39 cell proliferation was evaluated by assaying BrdU incorporation into DNA. Data are expressed as percent of control cells and are the mean \pm S.E. of three separate experiments.

(10 $\mu \mathrm{l})$ were analyzed by electrophoresis on $1.5 \%(\mathrm{w} / \mathrm{v})$ agarose gel, photographed and quantified by densitometric scanning.

$N F-\kappa B$ and STAT3 activation. The DNA-binding capacities of NF- $\mathrm{NB}$ (p65 subunit) and STAT3 were measured in nuclear extracts of the cells using the Nuclear Extract ${ }^{\mathrm{TM}}$ and TransAM ${ }^{\mathrm{TM}}$ NF-кB and STAT3 kits (Active Motif, Carlsbad, CA, USA) according to the manufacturer's instructions. Briefly, the assay uses a 96-well plate to which an oligonucleotide containing the NF- $\mathrm{\kappa B}$ or STAT3 consensus binding sites, i.e. 5'-GGGACTTTCC-3' or 5'-TTCCCGGAA-3', respectively, has been immobilized. The activated NF-кB or STAT3 contained in nuclear extracts specifically bind to these nucleotides. By using antibodies directed against epitopes on p65 or STAT3 that are accessible only when the factors are bound to target DNA, the NF- $\mathrm{KB}$ or STAT3 bound to the oligonucleotides is detected. Addition of a secondary antibody conjugated to horseradish peroxidase provides a sensitive colorimetric readout that is quantified by densitometry. The specificity of the assays was confirmed by contemporaneous incubations in the presence of an excess of the non-immobilized consensus oligonucleotides, as competitors, or of mutated consensus oligonucleotides. The results are expressed as arbitrary units (one unit is the DNA binding capacity shown by $1 \mu \mathrm{g}$ of whole cell extract from HeLa cells stimulated with TNF- $\alpha$ in the case of NF- $\mathrm{NB}$ and by $1 \mu \mathrm{g}$ of whole cell extract from HepG2 cells stimulated with IL-6 in the case of STAT3) $/ \mu \mathrm{g}$ protein of the MCF-7 or MCF-/R nuclear extracts.

Statistical analysis. Results are given as means \pm S.E. The significance of differences between means was evaluated by Student's t-test for unpaired samples and a $\mathrm{P}$ value $<0.05$ was considered significant.

\section{Results}

Antitumor effects of curcumin or MR 39 on the cells. Cell growth inhibition (MTS) assays revealed that the cytotoxic activity of curcumin in the MDR breast cancer cell line is at least equivalent to, or even slightly stronger than in its parental variant: after $72 \mathrm{~h}$ of treatment, the $\mathrm{IC}_{50}$ of curcumin calculated from four independent experiments was $29.3 \pm 1.7 \mu \mathrm{M}$ in MCF-7 and 26.2 $\pm 1.6 \mu \mathrm{M}$ in MCF-7R. The MR 39 derivative exhibited

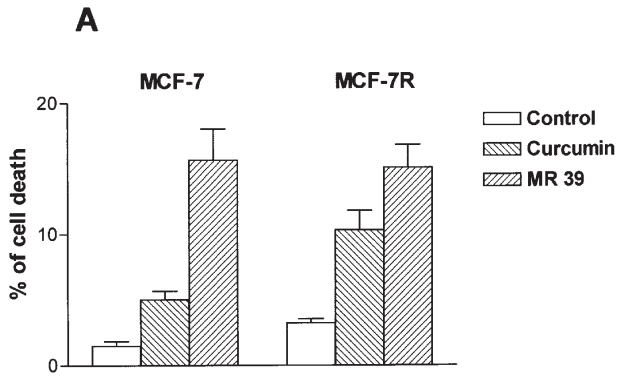

B
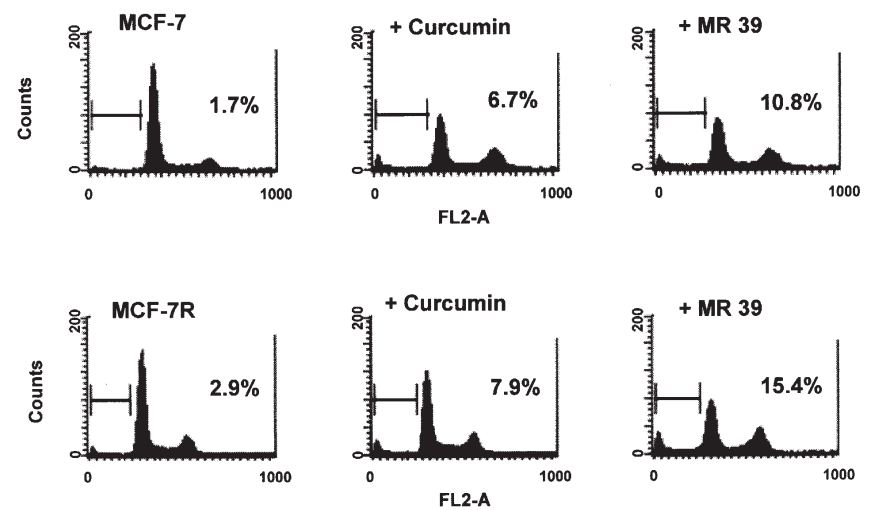

Figure 3. Induction of cell death by curcumin or MR 39 in MCF-7 and MCF-7R. (A) The cells were incubated with $25 \mu \mathrm{M}$ concentrations of curcumin or MR 39 for $48 \mathrm{~h}$ and thereafter cell death was evaluated by flow cytometry analysis of cell DNA stained with propidium iodide. Data are the mean \pm S.E. of four separate experiments. (B) Representative example of flow cytometry analysis of cell death and cell cycle in the cells treated with $25 \mu \mathrm{M}$ curcumin or MR 39. Shown are the profiles of propidium iodidestained DNA. Numbers in the panels indicate the $\%$ of the events in the preG $_{0}-\mathrm{G}_{1}$ position

Table I. Cell cycle changes induced by curcumin or MR 39 in MCF-7 and MCF-7R.

\begin{tabular}{lccc}
\hline & $\mathrm{G}_{0} / \mathrm{G}_{1}$ & $\mathrm{~S}$ & $\mathrm{G}_{2} / \mathrm{M}$ \\
\hline MCF-7 & $60.65 \pm 3.19$ & $18.34 \pm 2.21$ & $20.97 \pm 1.19$ \\
+ Curcumin $25 \mu \mathrm{M}$ & $48.58 \pm 4.50$ & $12.96 \pm 1.82$ & $38.44 \pm 4.74^{\mathrm{a}}$ \\
+ MR 39 25 $\mu \mathrm{M}$ & $39.00 \pm 7.60^{\mathrm{a}}$ & $21.83 \pm 6.48$ & $39.16 \pm 1.64^{\mathrm{b}}$ \\
MCF-7R & $56.41 \pm 1.44$ & $20.11 \pm 1.08$ & $23.47 \pm 0.71$ \\
+ Curcumin 25 $\mu \mathrm{M}$ & $56.54 \pm 2.96$ & $14.56 \pm 2.83$ & $28.89 \pm 1.11^{\mathrm{b}}$ \\
+ MR 39 25 $\mu \mathrm{M}$ & $48.38 \pm 6.53$ & $13.50 \pm 2.47^{\mathrm{a}}$ & $38.11 \pm 4.06^{\mathrm{a}}$
\end{tabular}

The cells were treated for $48 \mathrm{~h}$ with the agents and their distribution in the phases of the cell cycles was assessed through flow cytometry analysis of their DNA stained with propidium iodide and using ModFit $^{\mathrm{TM}}$ software, as described in Materials and methods. Data are the mean \pm S.E. of four separate experiments. ${ }^{\mathrm{P}} \mathrm{P}<0.05$ and ${ }^{\mathrm{b}} \mathrm{P}<0.01$ versus controls.

more potency than curcumin, both in the parental and in the MDR cell line: the $\mathrm{IC}_{50}$ of MR 39 was $13.1 \pm 1.6 \mu \mathrm{M}$ in MCF-7 and $12.0 \pm 2.0 \mu \mathrm{M}$ in MCF-7R. BrdU incorporation (Fig. 2) and cell death induction (Fig. 3) assays corroborated that curcumin 


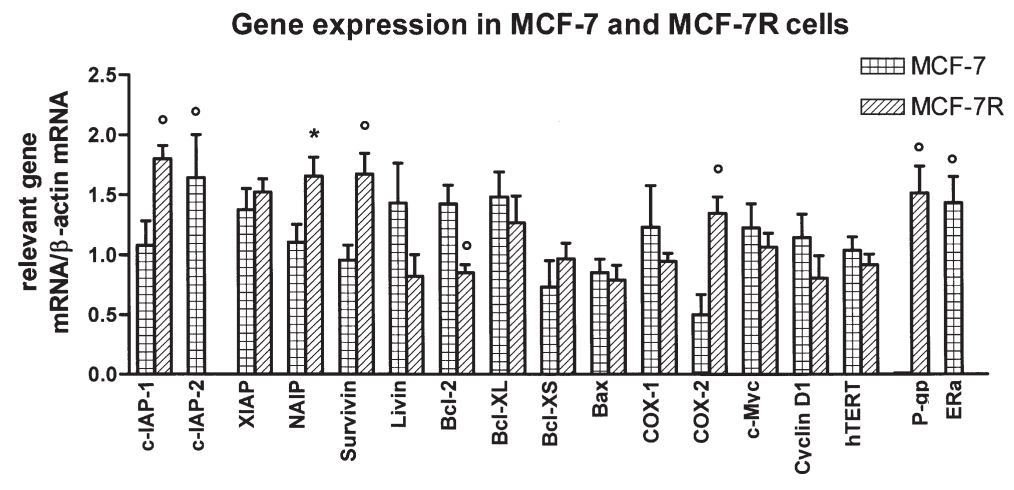

Figure 4. Basal gene expression in MCF-7 and MCF-7R. The level of expression of the different mRNAs was assessed by RT-PCR and densitometry as reported in Materials and methods. Data are expressed as arbitrary units (relevant mRNA/B-actin mRNA) and are the mean \pm S.E. of six independent observations. ${ }^{*} \mathrm{P}<0.05$ and ${ }^{\circ} \mathrm{P}<0.01, \mathrm{MCF}-7 \mathrm{R}$ versus MCF-7.
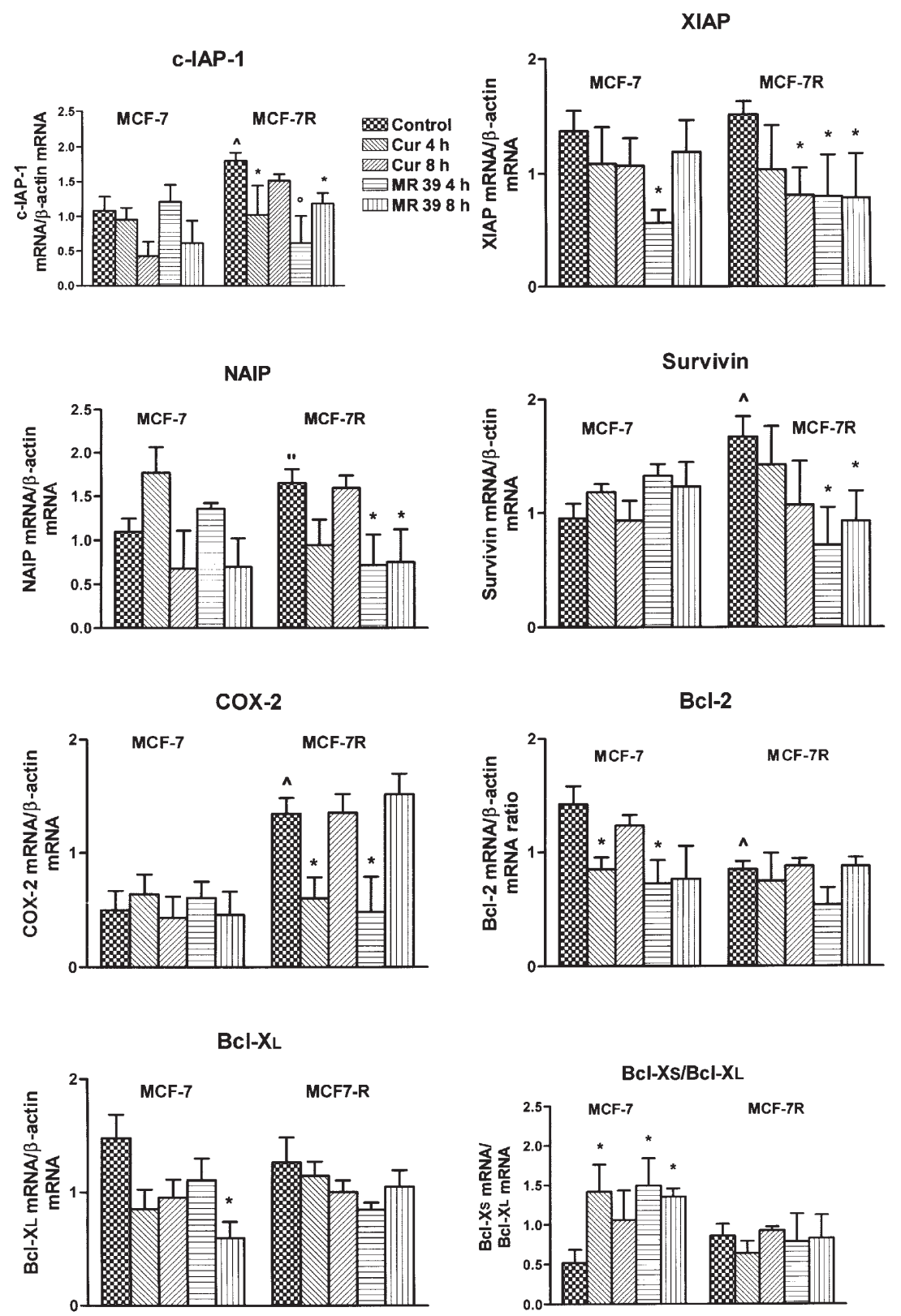

Figure 5. Effects of curcumin or MR 39 on gene expression in MCF-7 and MCF-7R. The cells were incubated with 25- $\mu$ M concentrations of the agents for 4 or $8 \mathrm{~h}$ and the expression of the different mRNAs was assessed by RT-PCR and densitometry as reported in Materials and methods. Data are expressed as arbitrary units (relevant mRNA/B-actin mRNA) and are the mean \pm S.E. of six independent observations for the controls and of three independent observations for the treatments. " $\mathrm{P}<0.05$ and ${ }^{\wedge} \mathrm{P}<0.01$, MCF-7R versus MCF-7. ${ }^{*} \mathrm{P}<0.05$ versus respective control. In the case of $\mathrm{Bcl}-\mathrm{X}_{\mathrm{S}} / \mathrm{Bcl}-\mathrm{X}_{\mathrm{L}}$, the ratios were calculated after normalization of the mRNAs to ß-actin expression. 

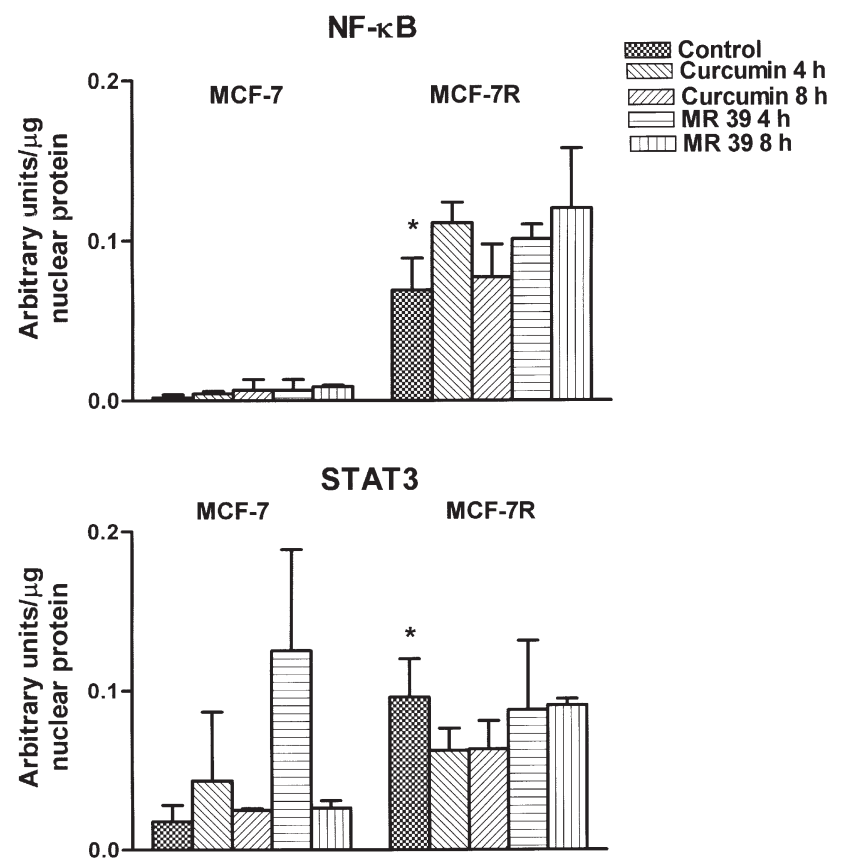

Figure 6. Effects of curcumin or MR 39 on NF-кB or STAT3 nuclear activation in MCF-7 and MCF-7R. The cells were incubated with $25-\mu \mathrm{M}$ concentrations of the agents for 4 or $8 \mathrm{~h}$ and the nuclear levels of activated $\mathrm{NF}-\kappa \mathrm{B}$ or STAT3 were measured as reported in Materials and methods. Data are expressed as arbitrary units $/ \mu \mathrm{g}$ of nuclear protein and are the mean \pm S.E. of four independent observations for the controls and of two or three independent observations for the treatments. ${ }^{*} \mathrm{P}<0.05, \mathrm{MCF}-7 \mathrm{R}$ versus MCF-7.

or, more potently, MR 39 exhibit in MCF-7R antiproliferative and cell death effects comparable to those achieved in MCF-7. The results on cell death were well confirmed by flow cytometry assessments of Annexin $\mathrm{V}$ binding to the cell surface (not shown). Further, analyses of the cell cycle (Fig. 3B and Table I) showed that, both in MCF-7 and MCF-7R, the agents caused significant accumulation of the cells in $\mathrm{G}_{2}-\mathrm{M}$; this effect has been frequently observed in curcumin-treated tumor cells and may be important to lead them to apoptosis $(8,9)$. Overall, these findings clearly indicate that the antitumor activity of curcumin or MR 39 is not reduced by the MDR condition of the MCF-7R cells.

Effects of curcumin or MR 39 on gene expression in the cells. We examined by RT-PCR the expression in the cell lines of different genes, including the IAPs, implicated in cell proliferation, survival and other pro-oncogenic processes. In basal conditions (Fig. 4), the MDRl gene product, P-gp, was expressed only in MCF-7R cells, and c-IAP-2 and ER $\alpha$ were only expressed in MCF-7. MCF-7 and MCF-7R exhibited a comparable expression of XIAP, livin, Bcl- $\mathrm{X}_{\mathrm{L}}, \mathrm{Bcl}-\mathrm{X}_{\mathrm{S}}$, Bax, COX-1, c-Myc, cyclin D1 and hTERT. However, cIAP-1, NAIP, survivin and COX-2 resulted to be significantly upregulated in MCF7-R with respect to MCF-7; in contrast, Bcl-2 was significantly more expressed in the parental cells.

Following 4- or 8-h treatments of the cells with curcumin or MR 39, there were no significant effects on the mRNA levels of c-IAP-2, livin, Bcl-X $\mathrm{s}$, Bax, COX-1, c-Myc, cyclin D1, hTERT, P-gp and ER $\alpha$ (data not shown). However, curcumin and, more strongly, MR 39 significantly down-regulated the
mRNAs of c-IAP-1, XIAP, NAIP, survivin and COX-2 in MCF-7R (Fig. 5). MR 39, but not curcumin, decreased XIAP mRNA also in MCF-7. On the other hand, treatment-related significant reductions in $\mathrm{Bcl}-2$ and $\mathrm{Bcl}-\mathrm{X}_{\mathrm{L}}$ levels were seen only in MCF-7, along with significant increases in the ratios between the pro-apoptotic splice form of Bcl-X, Bcl- $\mathrm{X}_{\mathrm{S}}$, and $\mathrm{Bcl}-\mathrm{X}_{\mathrm{L}}$. Thus, curcumin and MR 39 produced distinct modifications of the expression of relevant genes (mainly $\mathrm{Bcl}-2$ and $\mathrm{Bcl}-\mathrm{X}$ in MCF-7 versus IAPs and COX-2 in $\mathrm{MCF}-7 \mathrm{R}$ ) in the parental and MDR cells, which, on the other hand, displayed peculiar differences in their basal molecular patterns.

$N F-\kappa B$ and STAT3 activation. These analyses showed the presence of low nuclear levels of activated NF-кB (p65 subunit) and STAT3 in MCF-7; they were slightly, though significantly, elevated in MCF-7R (Fig. 6). Treatment with curcumin or MR39 did not significantly change the activation of the two factors in either cell line.

\section{Discussion}

The results of the present work indicate that the growthinhibitory and cell death inducing effects of curcumin or MR 39 are not hampered by the MDR condition of the MCF-7R cells. We have recently observed the same result comparing the antitumor effects of the two agents on HL-60 myeloid leukaemia and on an MDR-resistant variant of this cell line (unpublished observations). Importantly, both the MDR cell variants studied by us overexpress functional P-gp; thus, our data are in good agreement with other studies, which have found that curcumin is not extruded from cells by P-gp and that its antitumor activity is not affected in cells endowed with such a mechanism (9-11). For example, when compared to normal human mammary epithelial cells, another MDR variant of MCF-7, MCF/TH, even showed hypersensitivity to the cytotoxic and apoptotic effects of curcumin, thus also underlining the potential chemotherapeutic index of the compound (9).

In addition to the presence of $\mathrm{P}$-gp, in $\mathrm{MCF}-7 \mathrm{R}$ cells there were other multiple differences in gene expression with respect to MCF-7. First, they lacked ER $\alpha$ and anti-estrogen responsiveness, a characteristic already described in MDR variants of MCF-7 (12); speculatively, the finality of such a co-selection might be explained by the recent observation that estrogen signaling is able to down-regulate $\mathrm{P}$-gp in the same cells (13). Further, in MCF-7R there were significant variations in the mRNA levels of some pro-survival and proliferative factors, with increases in cIAP-1, NAIP, survivin and COX-2, but also reductions in c-IAP-2 and Bcl-2.

The molecular effects of curcumin and MR 39 were investigated after relatively brief ( 4 and $8 \mathrm{~h}$ ) periods of exposure to the compounds, in order to detect possible early changes responsible for, and not secondary to, the onset of cytotoxicity and cell death. Curcumin and, more potently, MR 39 produced early modifications in the amounts of relevant gene transcripts, which, interestingly, were mostly diverse (i.e. concerning Bcl-2, Bcl- $\mathrm{X}_{\mathrm{L}}$ and the $\mathrm{Bcl}-\mathrm{X}_{\mathrm{S}} / \mathrm{Bcl}-\mathrm{X}_{\mathrm{L}}$ ratio in MCF-7 versus the IAPs and COX-2 in MCF-7R) in the two cell lines. 
Among the possible explanations for such results, one might put forth the involvement of $\mathrm{ER} \alpha$ as well as of other transcription factors, such as NF- $\mathrm{KB}$ and STATs, possibly variably present in the cell lines. Previous studies have indeed shown that curcumin may exert anti-antitumor effects both in breast cancer estrogen receptor-positive and -negative cells through, respectively, ER-dependent and -independent, gene suppression mechanisms (14). It is also known that curcumin may inhibit a phosphorylation step on ER $\alpha$ necessary for its binding to its cognate DNA targets (15). On the other hand, it appeared logical to investigate NF- $\mathrm{KB}$ and STAT3 as possible targets of curcumin and MR39 in MCF-7R. In fact, their frequent abnormal activation in cancer cells may contribute to the processes of drug resistance (16-19); further, they can up-regulate the expression of many of the genes discussed, including MDR1/P-gp, the IAPs and COX-2 (16,20-23). Finally it is well documented that curcumin can inhibit at different stages the activation of both $\mathrm{NF}-\kappa \mathrm{B}$ and STAT3 $(6,7)$.

Our analyses showed, however, that the very low nuclear levels of activated NF-кB (p65 subunit) or STAT3 present in MCF-7 underwent only slight, though significant, elevation in MCF-7R. Moreover, curcumin or MR39 did not cause changes in the activation of NF- $\mathrm{KB}$ or STAT3 which could account for their different effects on gene expression in the two cell lines. Thus, alternative mechanisms might be examined, also considering that, reportedly, curcumin may affect gene transcription by other means, including interference with other transcription factors (e.g. AP-1) as well as with the processes of histone acetylation $(6,24,25)$. Such further investigations might also shed more light on the presently incompletely defined processes which regulate the expression of the IAPs and other drug resistance factors. On the other hand, clearly, the antitumor effects of curcumin may not depend solely on influences on gene transcription, but can also involve other mechanisms, including direct interactions with specific target molecules; there are also some cases [like that, e.g., concerning COX-2 (26)] in which the agent can affect both the function and the expression of a given molecule. With reference to this, it has been recently reported that MR 39 produces significantly higher direct inhibition of the COX-2 catalytic activity than curcumin (27), an interesting finding that may fit well with our observations.

In conclusion, our results suggest that curcumin may exhibit the remarkable property of modifying its molecular effects according to the diverse gene expression patterns existing in MDR cell lines compared to the parental ones, thereby maintaining unaltered antitumor activity. In other words, they seem to confirm curcumin's property of being a compound 'privileged' (28) for interaction with different unrelated targets, and its structure may form the basis for the development of more effective compounds. Accordingly, examining a series of novel curcumin derivatives, we have encountered the isoxazole analogue, which has shown more potent antitumor and molecular activities both in parental and in MDR tumor cells.

\section{Acknowledgements}

This study was supported by PRIN MIUR 20050512112005.

\section{References}

1. D'Alessandro N, Flugy A, Borsellino N and Travali S: Biology versus pharmacology in drug resistance. Oncol Rep 4: 207-210, 1997.

2. Reed JC: Dysregulation of apoptosis in cancer. J Clin Oncol 17: 2941-2953, 1999

3. LaCasse EC, Baird S, Korneluk RG and MacKenzie AE: The inhibitors of apoptosis (IAPs) and their emerging role in cancer. Oncogene 17: 3247-3259, 1998.

4. Notarbartolo M, Cervello M, Dusonchet L, Cusimano A and D'Alessandro N: Resistance to diverse apoptotic triggers in multidrug resistant HL-60 cells and its possibile relationship to the expression of P-glycoprotein, Fas and of the novel antiapoptosis factors IAP (Inhibitory of Apoptosis Proteins). Cancer Lett 180: 91-101, 2002.

5. Wheatley SP and McNeish IA: Survivin: a protein with dual roles in mitosis and apoptosis. Int J Cytol 247: 35-88, 2005.

6. Manson MM: Inhibition of survival signalling by dietary polyphenols and indole-3-carbinol. Eur J Cancer 41: 1842-1853, 2005.

7. Notarbartolo M, Poma P, Perri D, Dusonchet L, Cervello M and D'Alessandro N: Antitumor effects of curcumin, alone or in combination with cisplatin or doxorubicin, on human hepatic cancer cells. Analysis of their possible relationship to changes in NF- $\mathrm{\kappa B}$ activation levels and in IAP gene expression. Cancer Lett 224: 53-65, 2005.

8. Hanif R, Qiao L, Shiff SJ and Rigas B: Curcumin, a natural plant phenolic food additive, inhibits cell proliferation and induces cell cycle changes in colon adenocarcinoma cell lines by a prostaglandin-independent pathway. J Lab Clin Med 130: 576-584, 1997.

9. Ramachandran C and You W: Differential sensitivity of human mammary epithelial and breast carcinoma cell lines to curcumin. Breast Cancer Res Treat 54: 269-278, 1999.

10. Anuchapreeda S, Leechanachai P, Smith MM, Ambdukar SV and Limtrakul PN: Modulation of P-glycoprotein expression and function by curcumin in multidrug-resistant human $\mathrm{KB}$ cells. Biochem Pharmacol 64: 573-582, 2002.

11. Bielak-Mijewska A, Piwocka K, Magalska A and Sikora E: P-glycoprotein expression does not change the apoptotic pathway induced by curcumin in HL-60 cells. Cancer Chemother Pharmacol 53: 179-185, 2004.

12. Vickers PJ, Dickson RB, Shoemaker R and Cowan KH: A multidrug-resistant MCF-7 human breast cancer cell line which exhibits cross-resistance to antiestrogens and hormone-independent tumor growth in vivo. Mol Endocrinol 2: 886-892, 1988.

13. Mutoh K, Tsukahara S, Mitsuhashi J, Katayama K and Sugimoto Y: Estrogen-mediated post transcriptional downregulation of P-glycoprotein in MDR-1-transduced human breast cancer cells. Cancer Sci 97: 1198-1204, 2006.

14. Shao ZM, Shen ZZ, Liu CH, Sartippour MR, Go VL, Heber D and Nguyen M: Curcumin exerts multiple suppressive effects on human breast carcinoma cells. Int J Cancer 98: 234-240, 2002.

15. Callige M, Kieffer I and Richard-Foy H: CSN5/Jab1 is involved in ligand-dependent degradation of estrogen receptor $\alpha$ by the proteasome. Mol Cell Biol 25: 4349-4358, 2005.

16. Baldwin AS: Control of oncogenesis and cancer therapy resistance by the transcription factor NF-kappaB. J Clin Invest 107: 241-246, 2001.

17. Garg AK, Hortobagyi GN, Aggarwal BB, Sahin AA and Bucholz TA: Nuclear factor-kappa B as a predictor of treatment response in breast cancer. Curr Opin Oncol 15: 405-411, 2003.

18. Ikuta K, Takemura K, Kihara M, Nishimura M, Ueda N, Naito S, Lee E, Shimizu E and Yamauchi A: Overexpression of constitutive signal transducer and activator of transcription 3 mRNA in cisplatin-resistant human non-small cell lung cancer cells. Oncol Rep 13: 217-222, 2005.

19. Duan Z, Foster R, Bell DA, Mahoney J, Wolak K, Vaidya A, Hampel C, Lee H and Seiden MW: Signal transducers and activators of transcription 3 pathway activation in drug-resistant ovarian cancer. Clin Cancer Res 12: 5055-5063, 2006.

20. Wang CY, Mayo MW, Korneluk RG, Goeddel DV and Baldwin AS: NF-kappaB antiapoptosis: induction of TRAF1 and TRAF2 and c-IAP1 and c-IAP2 to suppress caspase- 8 activation. Science 281: 1680-1683, 1998.

21. Mitsiades N, Mitsiades CS, Poulaki V, Chauhan D, Richardson PG, Hideshima T, Munshi N, Treon SP and Anderson KC: Biologic sequelae of nuclear factor-kappaB blockade in multiple myeloma: therapeutic applications. Blood 99: 4079-4086, 2002. 
22. Sevilla L, Zaldumbide A, Pognonec P and Boulukos KE: Transcriptional regulation of the bcl-x gene encoding the antiapoptotic Bcl-xL protein by Ets, Rel/NFkappaB, STAT and AP1 transcription factor families. Histol Histopathol 16: 595-601, 2001.

23. Bentires-Alj M, Barbu V, Fillet M, Chariot A, Relic B, Jacobs N, Gielen J, Merville MP and Bours V: NF-kappaB transcription factor induces drug resistance through MDR1 expression in cancer cells. Oncogene 22: 90-97, 2003.

24. Balasubramanvam K, Varier RA, Altaf M, Swaminathan V, Siddappa NB, Ranga U and Kundu TK: Curcumin, a novel p300/CREB-binding protein-specific inhibitor of acetyltransferase, represses the acetylation of histone/nonhistone proteins and histone acetyltransferase-dependent chromatin transcription. J Biol Chem 279: 51163-51171, 2004.
25. Kang J, Chen J, Shi Y, Jia J and Zhang Y: Curcumin-induced histone hypoacetylation: the role of reactive oxygen species. Biochem Pharmacol 69: 1205-1213, 2005.

26. Gafner S, Lee SK, Cuendet M, Barthelemy S, Vergnes L, Labidalle S, Mehta RG, Boone CW and Pezzutto JM: Biologic evaluation of curcumin and structural derivatives in cancer chemoprevention model systems. Phytochemistry 65: 2849-2859, 2004.

27. Selvam C, Jachak SM, Thilagawathi R and Chakraborti AK: Design, synthesis, biological evaluation and molecular docking of curcumin analogues as antioxidant, cyclooxygenase inhibitory and anti-inflammatory agents. Bioorg Med Chem Lett 15: 1793-1797, 2005

28. Costantino L and Barlocco D: Privileged structures as leads in medicinal chemistry. Curr Med Chem 13: 65-85, 2006. 